\title{
Promotion of Domestic Tourism by Enhancing the Practice of Alternative Tourism as a Quality Measure to Satisfy and Retain National Tourists
}

\author{
Amina Chebli \\ École Polytechnique d'Architecture et d'Urbanisme (EPAU), Algiers, Algeria \\ Boualem Kadri \\ École des sciences de la gestion de l'Université du Québec à Montréal (ESG-UQAM), Montreal, Canada \\ Foued Ben Said \\ École Supérieure de Commerce de Tunis, Manouba, Tunisia
}

Received: 14 June 2021. Revision received: 17 July 2021. Accepted: 30 July 2021

\begin{abstract}
This study aims to study the satisfaction of national tourists with the tourism experience in the Sahara. It also seeks to examine the influence this has on the intention to return and spread positive word-of-mouth about this destination, work on its improvement to capitalize on the internal mobilities induced by COVID-19, and build a long-term relationship with them to strengthen regional attachment. Data were collected from 123 national tourists in Algeria using convenience sampling. Two analyses were carried out to process the data: a structural equation modeling approach to test and validate the hypotheses and textual analysis. The results show that among the five factors determining the quality of the Sahara experience, four factors significantly influence the satisfaction of domestic tourists: The scenic environment, the personal environment, entertainment, and reliability. It is deduced that the niche and responsible character of Saharan tourism is the main thing that satisfies tourists and ensures the success of tourism in the Sahara.
\end{abstract}

Key Words: Quality tourism experiences, tourist satisfaction and loyalty, national and alternative tourism

JEL Classification: Z32, Z38, J42, L833

Reference: Chebli, A., Kadri, B., Ben Said, F. (2021). Promotion of Domestic Tourism by Enhancing the Practice of Alternative Tourism as a Quality Measure to Satisfy and Retain National Tourists. Journal of Tourism and Services, 23(12), 61-85. doi: 10.29036/jots.v12i23.274

\section{Introduction}

Algeria's economic structure is extremely dependent on the hydrocarbon sector and is therefore vulnerable to the volatility of this market (Coville, 2010). Already facing political turmoil, as well as a health emergency, the country is likely to suffer greatly from the effects of COVID-19 on hydrocarbon prices. In addition, the country is reaching the limits of a severe economic crisis (Boudedja and al., 2020; Mouhoud, 2020). In a UN report maintaining a primary analysis of the socio-economic impact of COVID-19 on Algeria, it is recalled that it is imperative to undertake rapid measures to rid the country of its dependence on hydrocarbons. A series of proposals for a sustainable and resilient recovery is lined up. Tourism is proposed as an alternative to exhaustible resources, saving the country from the impending economic crisis (Kadri et al., 2016).

Meanwhile, it is difficult for the country to attract international tourists due to security risks, visa restrictions, inadequate air connectivity and/or insufficient infrastructure, it is worth thinking about the development of domestic tourism, whose economic contribution is no less (Gálvez and al., 2014; Adeloye 


\section{JOURNAL OF TOURISM AND SERVICES}

Issue 23, volume 12, ISSN 1804-5650 (Online)

www.jots.cz

et al., 2019). According to the UNWTO, the development of domestic tourism is a good opportunity for economic development and is described as a high economic impact generator.

In the first half of this year, as the virus situation began to be better understood and stabilised, post-pandemic tourist travel was directed towards easily accessible destinations, particularly within the same territory (Lew and al., 2020). Domestic tourism in Algeria, like what is happening elsewhere, is witnessing the emergence of this mobility. Indeed, as described by several researchers, the Covid-19 sanitary crisis presents an opening for the promotion of domestic tourism (Woyo, 2021). Therefore, institutional and private actors in Algeria must take advantage of the current situation and are invited to convince the millions of Algerian tourists who fly abroad every year to spend their holidays. These tourists leave a real fortune estimated by an expert at least 3 billion dollars to spend their holidays in their country of origin in the future.

After the easing of travel restrictions nationwide, the great desert (Sahara), with its commercial authenticity, has been much coveted by national tourists seeking spiritual refreshment and renewal after a period of unprecedented instability (Madani and al., 2020). The resumption of a leisure activity was the means of escape after a hard period of confinement and immobility, agitated by stress, difficulties and deprivation (Kurar, 2021). Tourism specialists even speak of a peak in demand recorded in the Algerian Sahara, during the post-covid phase, expressing the growth of an internal tourist demand that was previously lacklustre. Thus, the temporary suspension of international flights encourages the development of slow travel, which consists in traveling close to home (Molz, 2009). This could be an element to make Algerians discover or rediscover the tourist attractions of their country, which is an opportunity to develop domestic tourism in Algeria. The question is then: how to retain many of these tourists, i.e., build their loyalty, and attract new ones in the future?

Research studies have concluded that the highly experiential nature of tourism consumption makes tourists' loyalty dependent on the perceived quality of experience (QoE). This perceived quality systematically affects their satisfaction and generates direct and indirect effects on their intention and behavior toward the destination (Seetanah and al., 2020). A satisfied customer is likely to become a loyal customer, repeat visits, and participate in spreading positive word-of-mouth (Saayman and al., 2018). This highlights the need to understand satisfaction with different components of the tourism experience and the impact it has on tourists' intention to return. Thus, the challenge for tourism managers in Algeria is to investigate the perceived quality of the tourist experience, which represents a strategic axis on which it is necessary to work, in order to consider, in our case, retaining the new clientele, and to inscribe these emerging dynamics durably in the local economic development of the country. It is at this level that this study is situated.

To this end, this paper considers as a study case two Saharan destinations (the region of Illizi and the region of Tamanrasset) located in the south-eastern region of Algeria, one of the most popular tourist destinations in Saharan tourism. In other regions of the Sahara, tours are organised according to the model of beach tourism, with a product policy that is sometimes ill-adapted to the host context and that considerably distorts the Saharan imaginary (Amoah et al., 2021). In contrast, tourism in the south-eastern region of the country retains its authenticity (Gagnol 2018). The objectives of this research are as follows:

- Identify the quality of the attributes of Saharan tourism as perceived by domestic tourists.

- Assess the satisfaction of domestic tourists and assess the relationship between customer satisfaction and the quality of the attributes for the above items.

- Understand the affective elements of the Saharan tourism experience from the perspective of domestic tourists.

- Provide recommendations for improving weak attributes. 


\section{Literature review}

\subsection{Relationship between perceived quality and satisfaction}

The Sahara is one of the most popular destinations in Algeria for the local population and is known as a destination for experiential tourism (Minvielle and Minvielle 2010; Minvielle and Minvielle 2012). Experiential tourism is the emerging trend in the tourism industry. It is the opposite of mass tourism, which has traditionally focused on tours and package vacations with a low level of personal involvement. Experiential tourism encourages the visitor to participate as an actor in an experience that the operator makes possible (Smith, 2006). This transition requires adapting a destination experiential quality management model, which is a key issue in tourism experience management (Jennings and Nickerson 2006; Jennings et al. 2009). The Sahara has the necessary attributes to build an experiential offer that motivates individuals' emotions and becomes value-creating (Balogul and Brinberg 1997). Therefore, it is important to understand how best to manage all these attributes, whose interdependence and synergy create an experiential dynamic essential to a destination's positioning (Langlois 2003).

During the service experience, the customer interfaces with visible parts of the service, supported by invisible parts. Therefore, it is necessary to study the perceived QoE, considering both its tangible and intangible aspects, to achieve a holistic, reality-based design (Echtner and Ritchie, 1993). According to the most recent research on QoE, including Langlois (2003), five dimensions play a major and primary role in shaping perceived QoE:

Accessibility: first, physical accessibility, which means the ease of choosing a destination by the customer while considering the effort required to reach that destination. Then, directional information means the comfort for the customer to move to the destination or the place of service while considering the legibility and clarity. Secondly, the speed of the service concerns the time taken to perform the service.

Physical environment: the coherence of the decor and the theme that arouses sensations in the individual relating to his/her experiential environment, physical comfort, which refers to factors involving environmental stimuli (colours, design, space), musical comfort and the taste experience, and finally the olfactory experience: the association of a smell with a place, a point of sale or a brand.

Personalised relational environment: this refers to the social and relational environment such as the attractiveness of the staff's appearance, their attention and helpfulness towards the client.

Entertainment: this is the implementation of the experience so that it becomes memorable. This dimension includes theme and brand management, continuous entertainment as animation is essential in services, event programming, staff appearance and costumes that enhance the service brand, unique products that refer to the destination as small souvenirs.

Reliability: was presented by Zeithmal, Parasuraman, and Berry (1988) and reflects the ability of the service provider to deliver on time, the ability of the staff to assist the client, and the accuracy of the information provided. Reliability considers the psychological, social, physical and financial security of individuals.

The experience is described by the perceived quality of these elements, representing the quality of the product as assessed by the tourist. Thus, it is the tourists' overall impression of the inadequacy or supremacy of the service offered (Al-Ababneh, 2013; Marchat, 2018). When tourists use the service, they simultaneously compare the experience with their expectations, thus obtaining satisfaction/dissatisfaction. Authors such as (Bowie and Chang 2005; Perić and al. 2018; Chebli and Chabou Othmani 2020) explain that tourists' satisfaction is derived from the quality of services provided by the destination. Furthermore, the relationship between perceived quality and satisfaction has been well corroborated in the literature by different researchers (Parasuraman and al., 1985; Yüksel and Yüksel, 2001; Owusu-Frimpong and al., 2013).

Spreng et al., (1996) argued that tourist satisfaction is the result of QoE. The authors asserted that a high positive level of perceived quality leads to higher consumer satisfaction. In this study, this relationship is explored in the case of domestic tourism using the following hypothesis: 


\section{JOURNAL OF TOURISM AND SERVICES}

Issue 23, volume 12, ISSN 1804-5650 (Online)

www.jots.cz

H1. The perceived experiential quality of Saharan tourism services has a positive impact on the satisfaction of domestic tourists.

H1a: The quality of the physical and landscape environment as perceived by domestic tourists significantly influences their level of satisfaction.

H1b: The quality of the physical and scenic environment as perceived by domestic tourists has a significant influence on their level of satisfaction.

H1c: The quality of the personalised relational environment as perceived by domestic significantly influences their level of satisfaction.

H1d: The quality of entertainment as perceived by domestic tourists significantly influences their level of satisfaction.

H1e: The quality of reliability as perceived by domestic tourists significantly influences their level of satisfaction.

\subsection{Relationship between tourist satisfaction and loyalty}

Similarly, the tourism marketing literature has focused on the relationship between tourist satisfaction and loyalty. Loyalty can be defined as a "deep commitment to re-purchase or re-patronise a preferred product/service consistently in the future, thus leading to repeated purchases of the same brand or set of brands, despite situational influences and marketing efforts that may induce switching behaviour" (Oliver 1999). Customer loyalty thus reflects attitudes and behaviours toward services and their repeated use (Backman and Crompton, 1991). Finally, loyalty actions become a real issue, as they lead to re-purchase, the achievement of relational efficiencies, positive word-of-mouth, and the amortisation of costs incurred to build loyalty (Bacik et al. 2020). Therefore, studies recognise that understanding the factors that increase loyalty is valuable information for tourism managers and policymakers (Flavián et al., 2001)). For example, it is widely recognised that tourists' satisfaction with their stay is one of the most important factors influencing return visits.

Research suggests a significant relationship between tourist satisfaction, return intention, and positive word-of-mouth communication (Beeho and Prentice, 1997; Perić and al., 2020)). In this study, we examine this relationship in an effort to build a sustainable and value-generating relationship with domestic tourists. The second hypothesis is as follows:

H2. Satisfaction has a significant influence on tourist loyalty in Sabaran tourism.

H2a: Domestic tourists' satisfaction with a tourist destination positively influences their intention to revisit that destination.

H2b: Domestic tourists' satisfaction with a tourist destination positively influences their intention to spread positive word-of-mouth about that destination.

H2c: Domestic tourists' satisfaction with a tourist destination positively influences their intention to visit that destination if the price of services increases

Figure 1 illustrates the proposed research model to analyze the influence of service quality and Algerian tourists' satisfaction on future behavioral intentions. 
Figure 1. Research model

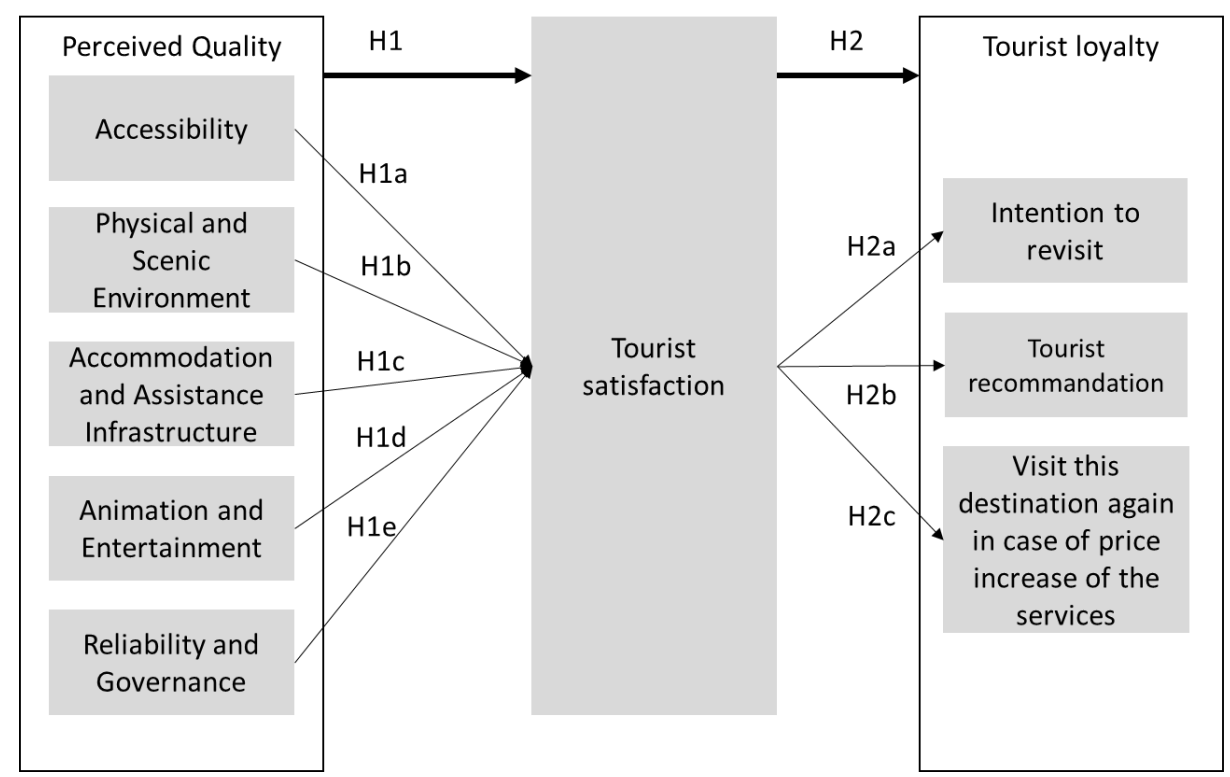

Source: Authors own conception

\section{Methods}

\subsection{Questionnaire design}

The quantitative method was used to collect the data for this study. The literature review on the topic of service quality, satisfaction and loyalty show that the questionnaire survey is the most commonly used instrument to conduct this type of study (Alegre and Garau, 2010). Guided by these reviews, our research instrument was developed based on the models by (Pawitra and Tan, 2003; Owusu-Frimpong and al., 2013; Perić and al., 2020). The questionnaire has five sections. The first section aims to obtain demographic information about the respondents. The second section includes 23 questions addressing tourists' perceptions of the various touristic services offered in the Sahara (Appendix 1). The third section contains 4 questions to measure satisfaction, while the fourth section includes 3 questions to measure the loyalty of domestic tourists (Appendix 1). Finally, due to the limited information on the offer that structures the tourist experience in the Algerian Sahara, the fifth section is an open-ended question, formulated with the aim of retrieving relevant data from direct and reliable sources on the components of the tourist experience, which complement those stated in the first section.

\subsection{Sample and data Collection}

The primary data was collected through a questionnaire survey method. The survey was conducted from January 25 to February 28, 2021. It was disseminated via social networks and on the official profile of a travel agency specialising in organising trips to the Sahara (Nboujiw community). The method used in this study is a non-probability convenience sampling method. Considering the lack of previous studies on the subject of the tourism experience in the Algerian Sahara and the complexity of the topic, to better understand the plural aspects, this study is intended to be pilot, so the method used in the study was a non-probability convenience sampling method. This method has been used and recommended in tourism research because it allows for the selection of respondents based on the convenience of the researcher (Naidoo and al., 2011; Araslı and Baradarani, 2014; Agyeiwaah and al., 2019). 


\section{JOURNAL OF TOURISM AND SERVICES}

Issue 23, volume 12, ISSN 1804-5650 (Online)

www.jots.cz

A total of 123 tourists participated in this study. Table 1 indicates that most of the tourists were male $(60.97 \%)$. Although generally, tourists visiting the Sahara are defined as an older population (Gagnol $2018)$, it can be noticed that more than half of the clientele is relatively young $(51.21 \%)$, between the ages of 25 and 35. The trip to the Sahara is most often made with friends or in organised groups (67.47\%).

Table 1. Demographic profile of the respondents

\begin{tabular}{ccc}
\hline \multirow{2}{*}{ Gender } & & Percentage \\
\hline \multirow{2}{*}{ Age group } & Male & $60.97 \%$ \\
\cline { 2 - 3 } & Female & $51.21 \%$ \\
\cline { 2 - 3 } & $18-24$ years & $11.38 \%$ \\
\cline { 2 - 3 } Marital status & $25-34$ years & $51.21 \%$ \\
\cline { 2 - 3 } & $35-49$ years & $28.45 \%$ \\
\hline Accompanying party & $50-64$ years & $08.94 \%$ \\
\cline { 2 - 3 } & Married & $31.70 \%$ \\
\cline { 2 - 3 } You have prepared your trip & Single & $68.29 \%$ \\
\cline { 2 - 3 } & With friends $/$ in an organised group & $31.70 \%$ \\
\cline { 2 - 3 } Occupation & Wlone & $67.47 \%$ \\
\hline & With the help of a travel agency & $43.82 \%$ \\
\cline { 2 - 3 } & Without a travel agency & $56.90 \%$ \\
\cline { 2 - 3 } & Retired & $01.62 \%$ \\
\cline { 2 - 3 } & Student & $17.07 \%$ \\
\cline { 2 - 3 } & State employee & $30.08 \%$ \\
\cline { 2 - 3 } & Liberal profession & $26.01 \%$ \\
\cline { 2 - 3 } & Other & $25.20 \%$ \\
\hline
\end{tabular}

Source: Authors' data

\subsection{Variables and measures}

The assessment of service quality is based on observation of the actual service provided or experienced (Kang, 2006). Respondents rated the perceived quality of services based on 23 items. These questions were adapted from the work of Langlois (2003). To compose the items to measure tourist satisfaction, numerous researches (Loureiro and González, 2008; Perić, Dramićanin, and Gašić, 2020) were reviewed. In the end, four questions were used to measure tourist satisfaction, while tourist loyalty was measured through three questions, generated from previous research (Cronin and Taylor, 1992; Lee and al., 2007; Pan and al., 2017). All measures were taken on a five-point Likert-type rating scale.

Regarding data processing, two types of factor analysis are used to test and validate the hypotheses. Firstly, a principal component analysis (PCA) and a confirmatory factor analysis (CFA) to investigate the internal validity of the measurement scales are used in our research. A structural equation analysis was conducted to test the relationships between the dimensions advocated by the research model. Statistical analyses of the data were carried out in SPSS 20 and AMOS 20.

The analysis of the open data consisted of descriptive statistics, including frequency counts. Although frequency counts do not provide statistically significant results, they provide some indication of the elements, such as emotional ones, considered to influence the quality of the tourism experience in the Sahara. 


\section{JOURNAL OF TOURISM AND SERVICES}

Issue 23, volume 12, ISSN 1804-5650 (Online)

www.jots.cz

\section{Results}

The data analysis in this study has two main parts. The first part consists of the study of the chosen measurement instrument was conducted to assess the dimensionality, reliability and validity of the constructs by using factor analysis (PCA and CFA), and then proceeded to an analysis by structural equation methods which aims to test the relationships between the dimensions advocated by the research model. Subsequently, in the second part, the analysis of the results of the open questions is carried out.

\subsection{Factorial analysis}

Validity of the measurement scale by Principal Component Analysis (PCA)

To examine the internal validity of the measurement scales used in our research, a Principal Component Analysis (PCA) is used. The (PCA), allows to reduce the number of variables in a database, to summarize the variance explained in a minimum number of factors to predict a reliable model fit, and to maximize the explanatory power of a set of variables (Hair and al., 2005). This analysis determines the correlation between the items and the principal component, which is the latent variable that will be introduced as an explanatory variable in the proposed structural model.

\section{- Accessibility}

Table 2. Purification and reliability of the "Accessibility" scale

\begin{tabular}{|c|c|c|}
\hline & Extraction & Component \\
\hline The price of a trip to the Sahara is affordable & 0.52 & 0.721 \\
\hline $\begin{array}{l}\text { The Sahara is an easily accessible destination. } \\
\text { (Transport means and infrastructure) }\end{array}$ & 0.703 & 0.839 \\
\hline Information on the destination is easily available & 0.612 & 0.782 \\
\hline Service in the Sahara is prompt and fast & 0.665 & 0.816 \\
\hline KMO measure of sampling adequacy & & 0.788 \\
\hline Bartlett's test of sphericity & 145.383 & $\mathrm{p}$-value 0.000 \\
\hline$\%$ of variance & 62.512 & \\
\hline Cronbach's Alpha & 0.798 & \\
\hline
\end{tabular}

Table 2 demonstrates that "Accessibility" dimension is strongly correlated with transport infrastructure and services, and less correlated with information and signage (0.612), and prices (0.52). The Kaiser Meyer Olkin (KMO) value of this PCA is 0.788 and qualifies as meritorious with an explanatory power of this component of $62.512 \%$ of the initial variance; the value of Cronbach's Alpha $(0.798)$ is close to 1 and indicates that the set of items that contribute to the accessibility variable are homogeneous.

- The physical and scenic environment

Table 3. Purification and reliability of the "Physical and scenic environment" scale

\begin{tabular}{lrr}
\hline & Extraction & Component \\
\hline The cleanliness of environment is good & 0.438 & 0.662 \\
\hline
\end{tabular}




\begin{tabular}{lrr} 
The Saharan cuisine is appetizing and very varied & 0.754 & 0.868 \\
\hline The Saharan music is very captivating & 0.789 & 0.888 \\
\hline The Sahara is endowed with attractive fairytale landscapes & 0.808 & 0.899 \\
\hline KMO measure of sampling adequacy & 0.733 & \\
\hline Bartlett's test of sphericity & 277.003 & p-value 0.000 \\
\hline \% of variance & 69.705 & \\
\hline Cronbach's Alpha & 0.852 &
\end{tabular}

Source: Authors' data

The "Physical and Scenic Environment" dimension is strongly correlated with cuisine, music, and the Saharan landscape, but less so with the cleanliness of the environment (Table 3). The KMO index of 0.733 can be described as average. It indicates that the correlations between the items are of average quality. Then, the result of Bartlett's sphericity test is significant $(p<0.0005)$ indicating that the items are factorizable. The value of Cronbach's alpha is 0.852 , which means that the items are homogeneous.

- Personalised relational environment

Table 4. Purification and reliability of the "Personalised relational environment" scale

\begin{tabular}{|c|c|c|}
\hline & Extraction & Component \\
\hline $\begin{array}{l}\text { In case of problems. you are well taken care of (in case of } \\
\text { worries you are given help. very professional. attentive and } \\
\text { dedicated tourist guides) }\end{array}$ & 0.703 & 0.839 \\
\hline The people of the Sahara are hospitable and welcoming & 0.695 & 0.834 \\
\hline $\begin{array}{l}\text { Saharans are convincing and offer personalised service and } \\
\text { care }\end{array}$ & 0.817 & 0.904 \\
\hline $\begin{array}{l}\text { The local people have good communication skills to } \\
\text { optimise the relationship with the tourists }\end{array}$ & 0.781 & 0.883 \\
\hline Saharan hotels have very courteous and helpful staff & 0.361 & 0.601 \\
\hline KMO measure of sampling adequacy & 0.844 & \\
\hline Bartlett's test of sphericity & 336.295 & $\begin{array}{l}\text { p-value } \\
0.000\end{array}$ \\
\hline$\%$ of variance & 67.141 & \\
\hline Cronbach's Alpha & 0.875 & \\
\hline
\end{tabular}

Analysis of the "Personalised relational environment" dimension shows that this latent variable is highly correlated with appreciation of the Sahara's courteous staff and residents, but is moderately correlated with the personalised service received at the hotels (Table 4). The KMO value indicates that this factoring is meritorious or excellent. The Cronbach's Alpha value indicates that the items in this dimension are homogeneous and reliable.

- Entertainment in the Sahara

Table 5. Purification and reliability of the "Entertainment in the Sahara" scale

\begin{tabular}{lll}
\hline & Extraction & Component \\
\hline The Saharan culture and atmosphere are very attractive & 0.861 & 0.928 \\
\hline
\end{tabular}




\begin{tabular}{|c|c|c|}
\hline $\begin{array}{l}\text { The Sahara is a destination rich in entertainment (hiking. } \\
\text { bivouac. } 4 \times 4 \text { safaris. camel rides. musical evenings. cultural } \\
\text { and historical discovery. etc.) }\end{array}$ & 0.893 & 0.945 \\
\hline In the Saharan hotels. the program of events is varied & 0.353 & 0.594 \\
\hline The Sahara is endowed with enchanting landscapes & 0.771 & 0.878 \\
\hline The Sahara is a memorable destination rich in memories & 0.886 & 0.941 \\
\hline KMO measure of sampling adequacy & 0.848 & \\
\hline Bartlett's test of sphericity & 570.865 & $\begin{array}{l}\text { p-value } \\
0.000\end{array}$ \\
\hline$\%$ of variance & 75.292 & \\
\hline Cronbach's Alpha & 0.917 & \\
\hline
\end{tabular}

The "Entertainment" dimension in Sahara depends mainly on the Saharan culture and atmosphere and the Saharan trek and its cultural and historical characteristics (Table 5). Programming only in hotels admits a small contribution to the formation of this dimension. The KMO index indicates that this Principal Component Analysis (PCA) has merit. The items that contribute to the formation of this dimension are homogeneous and reliable.

- Reliability and governance

Table 6. Purification and reliability of the "Reliability and governance" scale

\begin{tabular}{|c|c|c|}
\hline & Extraction & Component \\
\hline The Sahara is a vacation destination & 0.838 & 0.915 \\
\hline The tourist reception in the region is reliable and constant & 0.648 & 0.805 \\
\hline $\begin{array}{l}\text { The Sahara represents no psychological risk (stress. anxiety. } \\
\text { fear. etc.) }\end{array}$ & 0.846 & 0.92 \\
\hline The Sahara is a safe destination & 0.811 & 0.9 \\
\hline $\begin{array}{l}\text { In case of an accident. the Sahara is a destination where good } \\
\text { medical care is offered consistently and quickly }\end{array}$ & 0.105 & 0.323 \\
\hline KMO measure of sampling adequacy & 0.827 & \\
\hline Bartlett's test of sphericity & 371.2 & $\begin{array}{l}\text { p-value } \\
0.000\end{array}$ \\
\hline$\%$ of variance & 64.925 & \\
\hline Cronbach's Alpha & 0.853 & \\
\hline
\end{tabular}

This result shows that the "Reliability and governance" dimension is strongly correlated with the safety and relaxing climate of the Sahara, but Saharan tourism is not a reliable health tourism (Table 6). Health security and the quality of care offered by a tourist destination have an influence on the quality of the tourist experience, as they represent a guarantee in the prevention of diseases. The KMO index indicates that this Principal Component Analysis has merit (0.827). Bartlett's test indicates that the variables are factorizable, that is, they can be reduced to a single latent dimension $(\mathrm{p}$-value $=0.000)$. The items used in the construction of this component are homogeneous and reliable.

- Satisfaction 


\begin{tabular}{|c|c|c|}
\hline You are satisfied with your experience in the Sahara & Extraction & Component \\
\hline $\begin{array}{l}\text { Your trip to the Sahara provided you with the experience you } \\
\text { were looking for }\end{array}$ & 0.935 & 0.967 \\
\hline You are satisfied with the services provided & 0.902 & 0.949 \\
\hline In general. your experience is very positive & 0.744 & 0.862 \\
\hline You are satisfied with your experience in the Sahara & 0.946 & 0.973 \\
\hline KMO measure of sampling adequacy & & 0.836 \\
\hline Bartlett's test of sphericity & 630.339 & $\begin{array}{l}\text { p-value } \\
0.000\end{array}$ \\
\hline$\%$ de la variance & 88.158 & \\
\hline Alpha de Cronbach & 0.953 & \\
\hline
\end{tabular}

\section{Source: Authors' data}

This result shows that "Satisfaction" is an overall dimension that is highly correlated with the different components of customer satisfaction such as satisfaction with the services provided and satisfaction with the experience sought by Saharan tourism (Table 7). This Principal Component Analysis has merit $(\mathrm{KMO}=0.836)$. This dimension explains $88.158 \%$ of the initial total variance. The Cronbach's index indicates that the items in this dimension are reliable.

\section{Confirmatory Factor Analysis (CFA): Tests of the research hypotheses with AMOS}

To test the hypotheses of the research model, we first establish the goodness of fit. The goodness of fit of the model to the data was tested using the most common indices: the $\chi^{2} / \mathrm{ddl}$ ratio, the GFI (Goodness of Fit Index), the TLI (Tuckler-Lewis Index), the CFI (Comparative Fit Index), the RMSEA (Root Mean Square Error of Approximation), the RMR (Root Mean Square Residual), the SRMR (Standardised Root Mean Square). (Voir tableau 8). The acceptance thresholds of the model are the thresholds set by Hu and Bentler (1999). According to the results obtained, the fit is quite satisfactory.

Table 8. The goodness of fit index

\begin{tabular}{|c|c|c|c|c|c|c|c|c|c|c|}
\hline \multicolumn{7}{|c|}{ Absolute indices } & \multicolumn{2}{|c|}{$\begin{array}{l}\text { Parsimony } \\
\text { Measures }\end{array}$} & \multicolumn{2}{|c|}{$\begin{array}{l}\text { Incrementa } \\
1 \text { Fit Index }\end{array}$} \\
\hline index & $\chi^{2}$ & $\chi^{2} / \mathrm{df}$ & $\begin{array}{l}\text { SRM } \\
\mathrm{R}\end{array}$ & RFI & GFI & $\begin{array}{l}\text { RMSE } \\
\text { A }\end{array}$ & $\begin{array}{l}\text { PNF } \\
\text { I }\end{array}$ & $\begin{array}{l}\text { PGF } \\
\text { I }\end{array}$ & IFI & NFI \\
\hline $\begin{array}{l}\text { Acceptabilit } \\
\text { y threshold }\end{array}$ & & $<5$ & $\begin{array}{l}< \\
0.09\end{array}$ & $\begin{array}{l}>0 . \\
9\end{array}$ & $\begin{array}{l}>0.8 \\
5\end{array}$ & $<0.08$ & $>0.6$ & $>0.6$ & $>0.9$ & $>0.9$ \\
\hline Value & $\begin{array}{l}276.825 \\
*\end{array}$ & $\begin{array}{l}276.825 \\
/ 58= \\
4.773\end{array}$ & 0.087 & 0.92 & 0.87 & .079 & .74 & 0.75 & .961 & .948 \\
\hline
\end{tabular}

GFI = Goodness-of-Fit Index, NFI = Normed Fit Index, RMSEA $=$ Root Mean Square Error of Approximation, SRMR $=$ Standardised Root Mean Square Residual, RFI= relative fit index. PNFI and PGFI= parasimony NFI and GFI indices. * $\mathrm{p}<0.001$

Source: Authors' data

On this basis a structural equation analysis was conducted. This analysis consists of testing the following structural model and validating its hypotheses through the coefficients estimated by the 
maximum likelihood technique via the software AMOS 25. Figure 2 shows the estimated structural model. Table 9 below presents the results of the hypothesis test, i.e., the significance of the path.

Figure 2. AMOS structural model

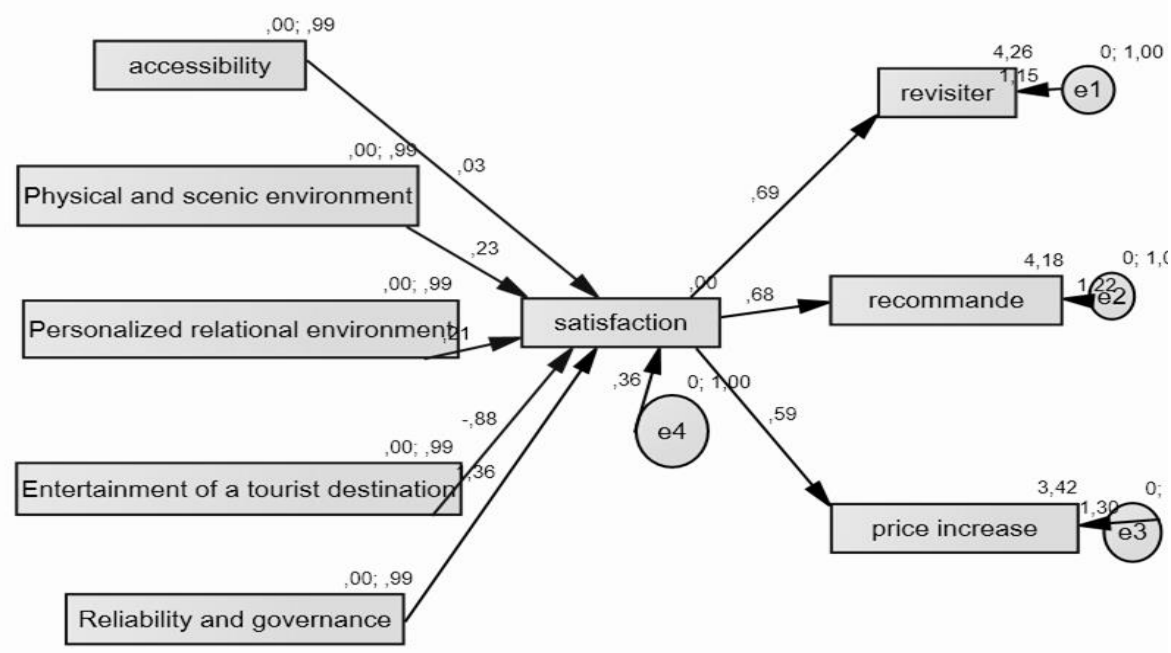

Source: Authors' data

Based on the results obtained, the hypotheses H1a cannot be accepted. While the hypotheses H1b, H1c, H1d, H1e, are accepted. The results show that the path Accessibility $\rightarrow$ Satisfaction is not statistically significant, while the other paths are. This result coincides with similar research in the tourism domain conducted by Pawitra and Tan (2003) and Owusu-Frimpong and al. (2013). However, for $\mathrm{H} 1 \mathrm{~d}$, although the correlation is validated, which confirms the hypothesis, the latter is negative, the coefficient is -.088 . This leads us to stipulate that emotional reactions have an explanatory power of satisfaction in this case. For this reason, explanations are provided to try to clarify the reasons for this relationship below (5.2).

The second analysis was performed to explore the path from satisfaction to loyalty in the model. The hypotheses H2a (0.68), H2b (0.68), H3b (0.59) ( $\mathrm{p}<0.001$ ) are accepted. The link between tourist satisfaction and loyalty is relatively strong and statistically significant and goes in the direction hypothetically presented. The obtained results are in agreement with similar research in this area (Lee and al., 2007; Perić et al., 2020).

Table 9. Hypothesis testing

\begin{tabular}{llll}
\hline Hypothesis & Coefficient & P-Value & Decision \\
\hline $\begin{array}{l}\text { H1a Accessibility } \rightarrow \\
\text { Satisfaction }\end{array}$ & 0.031 & 0.337 & $\begin{array}{l}\text { Not Supported } \\
\text { Hypothesis }\end{array}$ \\
\hline H1b Scenic $\rightarrow$ Satisfaction & .233 & $* * *$ & $\begin{array}{l}\text { Supported } \\
\text { Hypothesis }\end{array}$ \\
\hline H1c Relational $\rightarrow$ Satisfaction & .213 & $* * *$ & $\begin{array}{l}\text { Supported } \\
\text { Hypothesis }\end{array}$ \\
\hline $\begin{array}{l}\text { H1d Divertissement } \rightarrow \\
\text { Satisfaction }\end{array}$ & -.881 & $* * *$ & $\begin{array}{l}\text { Supported } \\
\text { Hypothesis }\end{array}$ \\
\hline
\end{tabular}




\begin{tabular}{llll} 
H1e Reliability $\rightarrow$ Satisfaction & 1.363 & $* * *$ & $\begin{array}{l}\text { Supported } \\
\text { Hypothesis }\end{array}$ \\
& & $* * *$ & $\begin{array}{l}\text { Supported } \\
\text { Hypothesis }\end{array}$ \\
$\begin{array}{l}\text { H2a Satisfaction } \rightarrow \text { Revisit } \\
\text { Intention }\end{array}$ & .688 & $* * *$ & $\begin{array}{l}\text { Supported } \\
\text { Hypothesis }\end{array}$ \\
$\begin{array}{l}\text { H2b Satisfaction } \rightarrow \\
\text { Recommend }\end{array}$ & .680 & & $\begin{array}{l}\text { Supported } \\
\text { Hypothesis }\end{array}$ \\
\hline $\begin{array}{l}\text { H2c Satisfaction } \rightarrow \text { Price } \\
\text { Increase }\end{array}$ & .592 & $* * *$ & \\
\hline & & & \\
& Source: Authors' data &
\end{tabular}

\subsection{Analysis of the open-ended question}

Out of a total of 123 tourists who responded to the questionnaire, 68 answered the open-ended question " Were there any elements that bothered you during your journey and that impacted on the quality of your experience?" This represents a response rate of $55.28 \%$. A statistical representation of the content was made using Alyze software, based on the respondents' verbatims. Table 10 is a term frequency table, which allows to identify the most recurrent expressions indicated by the respondents.

Table 10. Frequency summary

\begin{tabular}{llll}
\hline Expressions & Weighted (\%) & Gross density (\%) Occ & Occ \\
\hline $\begin{array}{l}\text { Absence information point and } \\
\text { tourist office }\end{array}$ & 1.71 & 4.73 & 3 \\
\hline $\begin{array}{l}\text { Expensive flight prices expensive } \\
\text { hotels }\end{array}$ & 1.63 & 5.68 & 3 \\
\hline $\begin{array}{lll}\text { Good atmosphere and simplicity } \\
\text { Direct flights }\end{array}$ & 1.57 & 3.79 & 3 \\
\hline Better communication & 1.39 & 2.52 & 4 \\
\hline $\begin{array}{l}\text { Enhancement of historical and } \\
\text { cultural sites and monuments }\end{array}$ & 1.39 & 1.89 & 6 \\
\hline Tourist brochures & 1.39 & 2.52 & 4 \\
\hline Tourist infrastructure & 1.39 & 2.52 & 4 \\
\hline $\begin{array}{l}\text { It is essential to think about the } \\
\text { professional training for local }\end{array}$ & 1.39 & 1.89 & 3 \\
\hline guides & & 3.15 & 5 \\
\hline Expensive hotels & 1.39 & 1.89 & 3 \\
\hline Saharan cuisine & 1.37 & 11.36 & 4 \\
\hline Catastrophic road conditions & 1.37 & 3.79 & 3 \\
\hline Service and rest stations & 1.3 & 7.57 & 3 \\
\hline Environmental awareness & 1.12 & 3.79 & 4 \\
\hline More residential facilities & 1.12 & 5.05 & 2 \\
\hline Improve catering services & 1.04 & 2.52 & 2 \\
\hline Unique experience & 0.92 & 1.26 & 2.52 \\
\hline Environmental education & 1.04 & & \\
\hline & Source: Authors' data & \\
\hline
\end{tabular}

The frequent use of these terms represents the elements that marked the tourism experience, supporting and enriching the analysis results in the previous section. It gives us insights into some 


\section{JOURNAL OF TOURISM AND SERVICES}

Issue 23, volume 12, ISSN 1804-5650 (Online)

www.jots.cz

manifest emotions beyond the cognitive aspect. These responses were grouped into four categories, which identify themes that appear repeatedsly:

- elements related to the lack of tourist information and communication include (lack of information point and tourist office, better communication, tourist brochures, professional training of local guides, etc.);

- elements related to the insufficiency and quality of tourism logistics (expensive flight prices, expensive hotels, direct flights);

- elements relating to the authenticity of the Sahara (good atmosphere and simplicity, unique experience, Saharan cuisine, etc.);

- elements related to environmental protection (environmental awareness, environmental education).

\section{Discussion}

Since a correlation is shown between perceived quality, satisfaction and loyalty, it is clear that to retain domestic tourists, they must be satisfied, which implies an improvement in the quality of tourism services offered in the south of the country. It is therefore important to act on the functioning of certain elements of the tourist experience (Tables 2, 3, 4, 5 and 6), while considering the information provided by the tourist respondents (Table 10). In light of these data, three lines of managerial recommendations are formulated.

\subsection{Improve the accessibility of the Sahara for tourists}

Although accessibility does not affect satisfaction, it does have an impact on the perceived QoE. The results in Table 2 show that among the accessibility elements that are weakly evaluated by tourists and influence the QoE, we find the value of the price of the destination (0.52). This evaluation is motivated by several reasons mentioned by most of them responding to the open-ended question, which we will address here point by point. The Sahara destination is considered unaffordable. As a general rule, the value of an asset depends on its utility and rarity. Scarcity is defined in terms of quantitative insufficiency: the lack of material goods on which people depend in part for their individual and social activity (Langlois, 1998). Thus, it is corroborated that anything that is scarce is generally expensive. For example, inadequate transportation infrastructure and low accommodation capacity cause airfare and accommodation prices to rise, as reported by tourists (Table 10).

The alternative of travelling by road, which is relatively cheaper, is not always obvious. It can be noted that the state of the roads and the terrible lack of rest areas and services make travelling by road difficult. Some extracts of tourists' testimonies are included to illustrate these facts betters:

"As for my experience, we went to Illizi by road and what is regrettable is the state of the roads, especially after

Hassi Masoud, which almost cost us our lives." (Respondent 63)

"... the journey is too exhausting by road, one is confronted with a very mediocre quality of the road, degraded pavement, absence of rest stations, and of motel corners." (Respondent 47)

Therefore, to improve the tourism experience, it is necessary to enhance the value of money of transportation (OCD 2016). Tourism stakeholders can ensure this through short-term intervention by enhancing the quality of road service to provide convenient and comfortable travel to encourage overland travel while considering mitigating negative environmental impacts. In particular, it is recommended that direct air links to and from Tamanrasset and Illizi, which are currently only served from the airport in the capital Algiers, be promoted, as travellers from other locations are forced to make a stopover in the latter, with additional costs. 


\section{JOURNAL OF TOURISM AND SERVICES}

Issue 23, volume 12, ISSN 1804-5650 (Online)

www.jots.cz

However, in the medium and long term, the Algerian government should consider an economic reform rethinking the economic scheme of the domestic air sector, considering the privatisation of airlines and the opening of investments to the private sector, especially for the creation of low-cost air transport companies and the development of domestic flights to the deep South (Sahara). Opening up domestic air transport to competition is a strategy for improving physical and financial accessibility (Petit and Venayre, 2018). The issue of affordability as mentioned in Table 9 also concerns accommodation facilities. Indeed, we also note reports of a lack of accommodation structures, as described below, responding to the open-ended question.

"There is a great disparity in terms of price and quality, between hotels, either a good quality hotel, with reservations difficult to obtain, due to low availability and at low prices, or others more affordable, but where the quality of services and hygiene left much to be desired." (Respondent 32)

"In the region there are few hotels, which makes them expensive, and bivouacs when you are with a family, with children, are not very convenient." (Respondent 13)

"The state must open up investment in the Sahara to build tourist complexes and infrastructures, which unfortunately remain insufficient." (Respondent 30)

This deficiency penalises the development of tourism in the Sahara and can directly influence the number of arrivals. The public authorities must remedy this deficiency by encouraging national and foreign economic operators to invest their capital in the Deep South to revive the sector and renovate the existing infrastructure. A reduction in costs accompanies the opening to competition. Nevertheless, any investment action must be subject to specifications specifying: sustainable construction conditions (ecological sanitary facilities, solar showers, etc.), in accordance with the requirements of regional urban planning (Z'riba, Agham-type architecture, etc.), the rigorous and exclusive use of local materials (raw earth, stone, palm wood), etc. In this way, the construction of tourist accommodation is compatible with the specificities of the site in which it is located (Bensadek, 2019). It is not a question of reproducing decontextualised, generic and identical models to those of the seaside model, as shown by the cases encountered in our neighbours. The Tunisian and Moroccan Sahara are models that modify the landscape and disrupt the sense of the Saharan experience, based on adventure and antinomic with modern daily life (Minvielle and Minvielle, 2010; Gagnol, 2018).

The challenge for tourism actors in Algeria would be to increase the accommodation capacity in the Great Sahara, while respecting the foundations of Saharan tourism, which develops around the actional and tribal dimension (Minvielle and Minvielle, 2014). It is therefore important to consider the diversification of accommodation modes, including alternative models that mark a break with the modern way of life: namely caravans as a mode of itinerancy and discovery of the Saharan environment and bivouacs as a mode of accommodation, guest houses, lodges, etc. However, it should be noted that the duration of an itinerant stay in the Sahara lasts on average one to two weeks (Gagnol, 2018), and this caravan mode can prove tedious in the long run, just like the hygiene conditions sometimes considered inconvenient. of itinerancy and discovery of the Saharan environment and bivouacs as a mode of accommodation, guest houses:

"The daily bygiene conditions are not simple and easy for everyone, you bave to adapt." (Respondent 60)

"It is very difficult to maintain good bygiene, we should think about putting showers when we return from activities, especially if they are physical." (Respondent 25)

This can influence the perception of the QoE and alter satisfaction. Therefore, it is necessary to plan and implement a convenient accommodation offer according to the tourist itineraries, so that itinerant travellers can punctuate their stay with stopovers, if necessary. However, it is always necessary to consider environmental preservation before the commercial interest, leading to a comfortable consumption caused by a certain demand. Finally, as a component of accessibility, the PCA results show that the level of information is low (0.61), which is confirmed by the responses to the open-ended question and provides information about the reasons for this assessment. Some of these reasons are:

"Improve the training of local guides, since most are only drivers." (Respondent 26) 


\section{JOURNAL OF TOURISM AND SERVICES}

Issue 23, volume 12, ISSN 1804-5650 (Online)

www.jots.cz

"There is a real need for visitor information posts." (Respondent 57)

"Public authorities should engage in a fight against fake tour guides, scams, and warn against false promises."

(Respondent 62)

To visit the Saharan region of Illizi and Tamanrasset, it is almost essential to be accompanied by a local guide. Local guides are often the only people with whom tourists interact during their stay, and it is to them that the public relations task of "encapsulating the essence of place" is entrusted (Salazar, 2006). Indeed, the role of local guides is to interpret the significant elements of the visited territory to convey information to tourists, offer explanations and develop narratives about the territory (Gwendal, 2012). The scientific literature explains that the dissemination of information by competent people is a strategic factor in the representation of the destination, influencing the quality of the tourist experience (Dahles, 2002).

Therefore, it is necessary to improve the quality of tour guide training to improve the quality level of experiential tourism. In the same vein, referring to what tourists say, one of the reasons for a poor evaluation of the quality of information is the lack of signage and information points. The signposting of routes is perceived as deficient. Therefore, it is also important to act on this level, especially since this deficiency is generally associated with a high source of stress and dissatisfaction (Kreziak and Frochot, 2011). Finally, the lack of information points is another problem raised by several tourists (Table 9). In the Sahara, mobile Internet coverage is very low, sometimes even non-existent, so that using this means of information is not an option. In this context, conventional information sources such as information offices become the only source of information. In this sense, these establishments are very well-placed to play a unique role in welcoming and orienting travellers. Thus, to improve access to tourism information, public authorities in the region are called upon to develop further this type of infrastructure, which plays an important role in improving the quality of the tourism experience (Lyu and Hwang, 2015; Simpson, 2016). Canal Pagès (2010) argued that information centres inform visitors about what they are asking for. Still, they can also go further and focus on the quality of service and communicate more interesting things and/or educate visitors about them the natural protected areas.

\subsection{A meeting of cultures and historical enrichment}

Tourism demand is geared towards searching for an authentic experience, which is qualified according to five characteristics: unique; real; human; non-commercial; social or emotional (Neault 2013). The Algerian Sahara offers a tourism experience that meets all of these characteristics, making it a prime destination for an authentic tourism experience. Indeed, the results show that the Saharan destinations that were the subject of this study, Illizi and Tamanrasset, offer an exoticism attached to the unique and real quality of the cultural (0.861) natural (0.808) attributes they contain. For example, in Illizi, the Tassili N'Ajjer Park, which contains more than 15,000 rock drawings and engravings of Neolithic age, dating from about 9 to 10,000 years before the present, which earned it its classification as a UNESCO World Heritage Site in 1972, and the Ahaggar National Park in Tamanrasset, classified as a World Heritage Site, is characterised by an exceptional wealth and diversity of flora and fauna. However, it appears that the rich potential of this place is not fully exploited. Among the comments recorded, some expressed frustration with the superficiality of the stories told about these landscapes, which do not reflect their true richness.

"The historical side was very much missing for my opinion. Even if our guide gave some explanations about the engravings we saw, in my opinion, it was still quite minimal." (Respondent 48)

"The Tassili N'Ajjer is simply magical. The air is very soft, and the landscapes are unique. My only regret is the impression I have of not having immersed myself in the history of the place." (Respondent 23)

To reinforce this attractiveness and improve the QoE, it is important to improve the communication around these objects, particularly by integrating a training course for local guides. It is important also to develop a signage system to highlight the singularity of these places and their symbolism, as mentioned above. It is necessary to support the traces of the millenary narratives by 


\section{JOURNAL OF TOURISM AND SERVICES}

Issue 23, volume 12, ISSN 1804-5650 (Online)

www.jots.cz

building a chronological discourse that reveals the site's identity and its survival while nourishing the legend associated with the site. Illizi and Tamanrasset also offer a memorial and emotional authenticity associated with the overall environment of the experience, i.e., the personal, scenic, and entertainment environment. We find that local traditions such as singing (0.789), Tuareg hospitality (0.695), traditional clothing (0.771), or the strong memorial dimension of the Sahara (0.886) are strong assets of the Saharan tourism experience. However, this memorial and emotional authenticity risks being undermined by large numbers of tourists and an apparent degree of acculturation. To better illustrate these common risks, we can examine some reports collected from tourists:

"I would have enjoyed my stay more if I had come alone, or with a small group of close friends, I find that the groups during the bivonacs and the trek are very numerous, it is a charm, but it is noisy, and it prevents the desired escape." (Respondent 5)

"I have already been up here five years ago, and I feel that a lot has changed in a short time, I feel that there is more folklore. It is not as real and pure as before." (Respondent 20)

"The mentality of the Tuareg has changed a lot, especially the young people, the introduction of "chicha" by the guides bothers me during my circuits." (Respondent 18)

The authors agree that tourism in the Sahara is an immersion experience where crowds of tourists are avoided as much as possible. The small group is a way to share emotions, to discover and understand also through the eyes of the other (Bouaouinate, 2009). Thus, to preserve the emotional authenticity of the tourism experience, it is important to regulate the problems of overcrowding in the camps, limiting the number of people per group to preserve the niche character that is an essential component of the Saharan experience. It was also stated (Respondents 5 and 20) that there is a risk of acculturation and folklorisation. For example, the Tuaregs, as can be seen, now offer chicha parties, even though this is not at all part of their culture. Or the tourists who suggest the presence of a regrettable folklorisation. Indeed, it is documented in previous work that the presence of a population outside the local community, such as tourists, leads both to an implicit but inevitable breakdown in the cultural and psychological cohesion of the Ex. (e.g. the Tuareg), and of the purpose of traditional dances and songs, which are no longer experienced in the same way by the local population, are inevitably perverted (Guay and Sylvain Lefebvre, 1995; Froger, 2012). Traditions can thus lose their true meaning, as expressed by the interviewees, and give way to folklore, itself falsified and stimulated as such for the pleasure of tourists.

However, to protect against folklorisation and acculturation, the key word is economic diversification in a vision of growing tourist demand. The local population's income should not be exclusively linked to tourism. The local population becomes obligated to use its history and culture as a commodity to respond to a culturally pre-constructed image by a tourist to satisfy him. This constraint leads to spectacular reconstructions and artificial representations of traditional Tuareg customs (Bouaouinate, 2008). Thus, local populations should not rush to tourism for their livelihood and move towards a monothematic local economy. It is essential to encourage the local population not to abandon traditional activities in the region, such as agriculture and livestock, by improving working conditions in these sectors, or to support the sub-Saharan trade dynamic by consolidating commercial traffic networks, which are expected to grow in light of the proposed trans-Saharan road infrastructure (Gregoire, 2011). Government commitment and leadership is likely to be important to initiate economic dynamics in the Saharan territories.

In the search for authenticity, the results show that Saharan cuisine is evaluated as a component that influences the tourist experience (0.754). However, to further improve the quality of tourism, it is necessary to give more importance to the latter, as some indications revealed a problem of valuation:

"There is no real choice in terms of food except for taguella and barbecue, so it is necessary to think about the people who don't like it." (Respondent 14).

"Saharan cuisine is not presented much in restaurants." (Respondent 32)

"Improving the quality and variety of food in the bivouacs." (Respondent 40) 


\section{JOURNAL OF TOURISM AND SERVICES}

Issue 23, volume 12, ISSN 1804-5650 (Online)

www.jots.cz

If not always, tourist experiences include a food experience, whether it is a visit to a market or factory, or simply a meal served at a local establishment (Salvador and El Euch Maalej, 2020). Although the discovery of food specialities does not figure prominently in the list of underlying motivations for travel, they are a valuable element of the travel experience, contributing to establishing an intimate encounter between the tourist and the local culture (Fraïssé and Stewart 2008). Indeed, let's take up one of the descriptions proposed by Boumeggouti (2006) on this subject. We can read that "...more than any other component of the local culture. Inin the cuisine and gastronomy, the contact with the civilisation and the local population is direct, stronger, and takes the form of a more or less intense experience". It thus appears that the action of eating is at the foundation of collective identity, given that cooking and table manners are culturally determined and place the eating tourist in a social universe, that is, in a cultural order (Poulain, 1998).

Food is thus an integral part of tourist discovery and is considered a "memorable" experience, which plays a role in the quality and success of the trip (Bessière and al., 2016; Salvador and El Euch Maalej, 2020). Thus, to improve the quality of the tourism experience in the Algerian Sahara, to satisfy and retain domestic tourists, those in charge of the activity must take steps to move food from a purely functional, peripheral, or even negligible status in the context of the trip to that of valued elements (Csergo, 2006). The valorisation and patrimonialisation of traditional food in the Algerian Sahara can be seen as a strategy for valorising the food experience.

Although the quality of the variables is rated as very good, we find that tourists are dissatisfied with the entertainment component as a whole (-.0881). This leads us to say that satisfaction may be completely detached from the intrinsic quality of the service provided in this case. And that it is linked to an affective dimension. The emotional reaction, independent of the disconfirmation of expectations, most probably explains the satisfaction in this situation (Dubé-Rioux, 1990; Ladhari, 2007). However, as discussed above, the results of the textual analysis give us additional information from which we can deduce and formulate some of these negative emotions, such as the fear of acculturation and overcrowding, or the frustration of tourists who cannot easily understand the area, due to the lack of information that causes a lack of legibility (Hall and Härkönen 2006).

\subsection{Environmental education}

The tourist sites of Illizi and Tamanrasset, comprise immense natural reserves (animal and vegetable) fragile, of particular interest, necessary to preserve. Nevertheless, some of the collected testimonies, which we report below, report a threatening degradation of an altered landscape. However, preserving the natural environment touches on several aspects such as water resource management, air emissions, noise pollution, etc. From the testimonies collected, it appears that it is mainly the issue of waste that worries tourists. Indeed, if some tourists have an environmental maturity, it is unfortunately not the case of all. Moreover, these different comments corroborate the results of the principal component analysis, which indicate a low evaluation of the level of cleanliness and environment (0.438).

"It is necessary to communicate about pollution among tourists. The Tuareg do not dare to prevent waste. A prevention system should be set up so that tourists collect their waste. We are heading for a great ecological disaster and it is getting worse every year." (Respondent 37)

"Saharan tourism is very prosperous and, on the rise, we just need to think about protecting the environment." (Respondent 38)

"As I am in the associative field, I frequently visit the places and I notice an increasing degradation, my greatest regret is to see waste everywhere: water bottles, plastic bags, cans, etc. The tourist and the inhabitant are both destroyers of nature." (Respondent 56)

"I was dismayed by the lack of civic-mindedness of the tourists in northern Algeria. Bad behaviour. No responsibility for the ecology. They leave plastic bags and cups hying around in the middle of a virgin landscape..." (Respondent 65) 


\section{JOURNAL OF TOURISM AND SERVICES}

Issue 23, volume 12, ISSN 1804-5650 (Online)

www.jots.cz

The macro-waste that some tourists do not fail to leave behind them are real blinkers that degrade the landscape and constitute real reservoirs of microbes and other harmful products for the fauna and flora. The consequences of these disrespectful behaviours are latent and disastrous for the environment. The degradation is progressive but certain (Minvielle and Minvielle, 2010). Given the new tourism dynamics prevailing in the Sahara, the current situation is a shared responsibility between the immature and unaware tourist, the negligent tourist agent, and the overwhelmed or passive local actors. Thus, waste management is a two-way challenge. In addition to the benefits of preserving the natural environment, it is strongly conceded that a clean and waste-free atmosphere will certainly improve the quality of the destination as well as the tourism experience, and thus represents a sustainable condition of competitive advantage for tourism communities (George, 2007; Dileep, 2014). Thus, it is a matter of satisfying the tourist while preserving the environment.

The challenge is to establish a participatory waste management mechanism between the local community, travel agencies and tourists that meet the needs and interests of all these stakeholders (Willmott and R. Graci, 2012). On the one hand, local stakeholders should plan to increase their local management capacity to respond to potential new tourism dynamics and equip themselves with sorting stations, incineration and treatment plants, etc. On the other hand, they should submit charters of conduct to all travel agencies operating in their territory to participate in management by collecting the waste produced during tours and at bivouac sits, and bringing it back to the village or town of departure for sorting and incineration later. The latter are called upon to set a good example to tourists. It is also the responsibility of tour operators and guides to take action to change tourist waste behaviour by encouraging waste reduction, improving education and awareness of the consequences of waste and desired practices. For example, encouraging tourists to adopt more environmentally friendly behaviours, such as using reusable water bottles, cloth bags, providing waste bins to make camp cleaning more accessible, etc. The aim is not to make them feel guilty but to encourage them to take appropriate action.

\section{Conclusion}

Domestic tourism is described as the panacea for the development of sustainable tourism (Kabote 2020). Thus, in the perspective where Algeria intends to make tourism an active economic sector with sustainable spin-offs, the current situation marked by the growing interest in domestic tourism is a perfect opportunity to act. To benefit in the long term from these internal mobilities that COVID-19 has promoted, and thus increase their development potential, the United Nations specialised agency for tourism, UNW'TO, has highlighted the need to understand internal tourism, taking into account its specificities. The aim is to ensure a match between tourism supply and demand while guaranteeing the quality of services to satisfy tourists. It is in this perspective that this research is being carried out. To better understand the perceived quality of the Saharan tourist experience by national tourists and their level of satisfaction, to then work towards building loyalty to the destination.

In the tourism industry, perceived service quality, satisfaction, and tourists' loyalty have been examined in different contexts. However, these aspects have not been addressed in tourist satisfaction with the tourism experience in an Algerian economy. This research has filled this gap. Regarding the theoretical contributions of this research, the study results support the relevance of previous studies that satisfaction incorporates both cognitive and affective processes. Through textual analysis, we have a better understanding of the negative affective reactions induced by the tourism experience, and these results provide a basis for improving satisfaction. Indeed, considering the affective reactions helps to clarify the issue of satisfaction. Institutional actors should be better equipped to evaluate their attributes' quality and report detailed information on customer satisfaction to develop future highly attractive attributes. 


\section{JOURNAL OF TOURISM AND SERVICES}

Issue 23, volume 12, ISSN 1804-5650 (Online)

www.jots.cz

Thus, following the analysis and discussion of the results obtained, it emerges that the quality of the tourist experience in the Sahara as defined by the nationals who participated in this work is based on the immersive cultural experience, the search for distance from the superfluity of civilisation and urban noise, and the desire for direct contact with the local population. It also appears that the motivation for travel is in some cases a cultural and learning need, for which there is a demand for better training of guides to improve the quality of information. An interest in the environment is also felt. Tourists do not have a passive attitude. They denounce the problem of waste and express their annoyance at the uncivil behaviour of some tourists. These elements reveal significant parameters that characterise alternative tourism. These results are in line with Benbelaid (2019), who demonstrated in her thesis the sustainable nature of tourism in the Sahara, as practiced by national tourists.

Thus, to retain this national clientele, it is the responsibility of tourism managers to preserve this fragile environment and act mainly on improving and preserving the quality of the scenic and personal environment and the authenticity that characterises the attributes of entertainment. Indeed, as can be seen, to satisfy domestic tourists, the Sahara does not need real estate in its archaisms. This archaism is today the source of the success of the Saharan tourist experience. Therefore, it is necessary for tourism stakeholders in Algeria to capitalise on their efforts to ensure that the tourism offer in the Sahara reconciles the preservation of the cultural heritage, the local and natural environment, and the integration of the local population into the tourism experience. This is becoming increasingly necessary to create an authentic offer, which is claimed, as we have mentioned, to ensure that the offer remains in line with the precept of alternative tourism, which is currently responding to the emerging demand from tourists COVID-19 pandemic.

- Recommendations for future research

This research provides a basis for further research perspectives that would complement it. For future research, it would be interesting to study the impact of demographic characteristics (age, gender, occupation) on the relationship between perceived quality, satisfaction and tourist loyalty. Furthermore, to consider integrating and statistically verify the impact of the affective dimension, highlighted by the textual analysis on satisfaction. It is assumed and investigated that the integration of emotional reactions would improve the explanatory power of the variance of satisfaction. It is also planned to analyse to what extent the integration of a sustainable development approach could improve the experiential quality of tourism, the level of satisfaction and the loyalty of tourists, is also a relevant path to explore.

\section{References}

1. Adeloye, D., Carr, N., \& Insch, A. (2019). Domestic tourism and terrorism : An ignored field. Tourism Recreation Research, 44(3), 382-386. https://doi.org/10.1080/02508281.2019.1626117

2. Agyeiwaah, E., Otoo, F. E., Suntikul, W., \& Huang, W.-J. (2019). Understanding culinary tourist motivation, experience, satisfaction, and loyalty using a structural approach. Journal of Travel \& Tourism Marketing, 36(3), 295-313. https://doi.org/10.1080/10548408.2018.1541775.

3. Al-Ababneh, M. (2013). Service Quality and its Impact on Tourist Satisfaction. Interdisciplinary journal of contemporary research in business, 4(12).

4. Alegre, J., \& Garau, J. (2010). TOURIST SATISFACTION AND DISSATISFACTION. Annals of Tourism Research, 37(1), 52-73. https://doi.org/10.1016/j.annals.2009.07.001 .

5. Amoah, J., Jibril, A.B., Luki, B.N., Odei, M.A. \& Yawson, C. (2021). Barriers of SMEs' sustainability in sub-saharan Africa: a pls-sem approach. International Journal of Entrepreneurial Knowledge, 9(1), 10-24. https://doi.org/10.37335/ijek.v9i1.129 


\section{JOURNAL OF TOURISM AND SERVICES}

Issue 23, volume 12, ISSN 1804-5650 (Online)

www.jots.cz

6. Arasl, H., \& Baradarani, S. (2014). European Tourist Perspective on Destination Satisfaction in Jordan's Industries. Procedia - Social and Behavioral Sciences, 109, 1416-1425. https://doi.org/10.1016/i.sbspro.2013.12.645.

7. Bacik, R., Fedorko, R., Gavurova, B., Olearova, M., \& Rigelsky, M. (2020). Hotel Marketing Policy: Role of Rating in Consumer Decision Making. Marketing and Management of Innovations, 2, 11-25. http://doi.org/10.21272/mmi.2020.2-01

8. Backman, S. J., \& Crompton, J. L. (1991). Differentiating Between High, Spurious, Latent, and Low Loyalty Participants in Two Leisure Activities. Journal of park and recreation administration, Vol. 9(No. 2,), 1-17.

9. Beeho, A. J., \& Prentice, R. C. (1997). Conceptualizing the experiences of heritage tourists. Tourism Management, 18(2), 75-87. https://doi.org/10.1016/S0261-5177(96)00103-3.

10. Benbelaid, Y. (2019). Tourisme alternatif à Djanet et Taghit: Enjeux socio-économiques et environnementaux. Thèse soumise à l'Université d'Ottawa.

11. Bensadek, C. (2019). Les aires protégées du Sahara algérien, entre traditions et enjeux contemporains: Perspectives d'écodéveloppement au cœur des parcs culturels du Tassili-Ahaggar (Algérie). Maghreb - Machrek, N²39(1), 117. https://doi.org/10.3917/machr.239.0117.

12. Bessière, J., Mognard, É., \& Tibère, L. (2016). Tourisme et expérience alimentaire: Le cas du SudOuest français. Téoros, 35(2). https://doi.org/10.7202/1040346ar.

13. Bouaouinate, A. (2008). Les acteurs locaux du tourisme de désert au Maroc: Cas de l'erg Chebbi et de Zagora-M'hamid. Université Mohammed V - Agdal - Rabat.

14. Bouaouinate, A. (2009). Erg Chebbi (Maroc): Une dynamique touristique interrompue par une inondation au désert. Annales de géographie, 667(3), 332. https://doi.org/10.3917/ag.667.0332.

15. Boudedja, K., Kadi, M., Benamirouche, H., Medjoub, R., Ameur, F., Hernoun, F., \& Meskine, N. (2020). L'après COVID-19: Une économie ouverte et durable seule possibilité pour juguler l'impact de la pandémie. Les Cahiers Du Cread, Vol. 36(n 03).

16. Boumeggouti, D. (2006). Le patrimoine culinaire dans la dynamique touristique marocaine. Horizons Maghrébins - Le droit à la mémoire, 55(1), 122-132. https://doi.org/10.3406/horma.2006.2384

17. Bowie, D., \& Chang, J. C. (2005). Tourist satisfaction: A view from a mixed international guided package tour. Journal of Vacation Marketing, 11(4), 303-322. https://doi.org/10.1177/1356766705056628.

18. Canal Pagès, E. (2010). Tourist information centres: limited to providing information? . PASOS: Revista de Turismo y Patrimonio Cultural Vol. 8, No. 4, pp. 669-671

19. Chebli, A., \& Chabou Othmani, M. (2020). Composants « structurels » de l'attractivité touristique. Loisir et Société / Society and Leisure, 1-17. https://doi.org/10.1080/07053436.2020.1788786

20. Coville, Thierry. (2010). L'économie algérienne, toujours malade de sa dépendance aux hydrocarbures ? Les Cahiers de l'Orient 100(4):41. doi: 10.3917/lcdlo.100.0041.

21. Cronin, J. Joseph, and Steven A. Taylor. 1992. 'Measuring Service Quality: A Reexamination and Extension'. Journal of Marketing 56(3):55-68. doi: 10.1177/002224299205600304.

22. Csergo, J. (2006). Quelques jalons pour une histoire du tourisme et de la gastronomie en France. Téoros, 25-1, 5-9.

23. Dahles, H. (2002). The Politics of Tour Guiding. Annals of Tourism Research, 29(3), 783-800. https://doi.org/10.1016/S0160-7383(01)00083-4 .

24. Dileep, M. R. (2014). Waste management, tourism. In J. Jafari \& H. Xiao (Eds.), Encyclopedia of Tourism (pp. 1-2). Springer International Publishing. https://doi.org/10.1007/978-3-31901669-6 635-1.

25. Echtner, C. M., \& Ritchie, J. R. B. (1993). The Measurement of Destination Image: An Empirical Assessment. Journal of Travel Research, 31(4), 3-13. https://doi.org/10.1177/004728759303100402. 


\section{JOURNAL OF TOURISM AND SERVICES}

Issue 23, volume 12, ISSN 1804-5650 (Online)

www.jots.cz

26. Flavián, C., Martinez, E., \& Polo, Y. (2001). Loyalty to grocery stores in the Spanish market of the 1990s. Journal of Retailing and Consumer Services, 8(2), 85-93. https://doi.org/10.1016/S0969-6989(99)00028-4.

27. Fraïssé, C., \& Stewart, I. (2008). Articulation entre deux formes de croyances: Principe d'incorporation et stéréotypes de sexe. Les cahiers internationaux de psychologie sociale, Numéro 77(1), 15. https://doi.org/10.3917/cips.077.0015.

28. Froger, G. (2012). Le tourisme durable dans les Suds: Solution ou mirage? Mondes en développement, n¹57(1), 29. https://doi.org/10.3917/med.157.0029 .

29. Gagnol, L. (2018). Marginalité, spécificités et instabilité du tourisme saharien. Bulletin de l'Association de Géographes Français, 95(2), 290-307. https://doi.org/10.4000/bagf.3319 .

30. Gálvez, T. G., Romero, J. M., \& Devesa, M. J. S. (2014). Measuring and Analysing Domestic Tourism: The Importance of an Origin and Destination Matrix. Tourism Economics, 20(3), 451472. https://doi.org/10.5367/te.2013.0286.

31. George, Babu P. (2007). Tourism and environmental quality management: comparative perspectives. ASEAN Journal on Hospitality and Tourism (Vol 6, No 1 (2007)):29-44.

32. Gregoire, E. (2011). Réseaux, urbanisation et conflits au Sahara. Insaniyat / -29 إنسانيات, 51-52, 42. https://doi.org/10.4000/insaniyat.12854 .

33. Guay et Sylvain Lefebvre, P. (1995). Univocite et variabilite des impacts sociaux du tourisme international: Quelques elements de reflexion. The Tourist Review, 50(4), 20-34. https://doi.org/10.1108/eb058204.

34. Gwendal, S. (2012). Le rôle des informations touristiques dans la médiatisation du territoire de visite: Le cas d'un voyage semi-organisé à Paris. Téoros, 31-2, 42-50.

35. Hair, J. F., \& C. Black, W. (Eds.). (2010). Multivariate data analysis (7th ed). Prentice Hall.

36. Hall, C. M., \& Härkönen, T. (Eds.). (2006). Lake Tourism: An integrated approach to lacustrine tourism systems. Channel View Publications.

37. Hu, L., \& Bentler, P. M. (1999). Cutoff criteria for fit indexes in covariance structure analysis: Conventional criteria versus new alternatives. Structural Equation Modeling: A Multidisciplinary Journal, 6(1), 1-55. https://doi.org/10.1080/10705519909540118

38. Jennings, G., \& Nickerson, N. P. (2006). Quality tourism experiences. Elsevier ButterworthHeinemann.

39. Jennings, G., Lee, Y.-S., Ayling, A., Lunny, B., Cater, C., \& Ollenburg, C. (2009). Quality Tourism Experiences: Reviews, Reflections, Research Agendas. Journal of Hospitality Marketing \& Management, 18(2-3), 294-310. https://doi.org/10.1080/19368620802594169 .

40. Kabote, F. (2020). Contribution of Domestic Tourism to Sustainable Tourism Development. In Tourism [Working Title]. IntechOpen. https://doi.org/10.5772/intechopen.93646 .

41. Kadri, B., Benhacine, D (Eds.). (2016). La mise en tourisme des territoires dans le monde arabe. L'Harmattan.

42. Kang, G. (2006). The hierarchical structure of service quality: Integration of technical and functional quality. Managing Service Quality: An International Journal, 16(1), 37-50. https://doi.org/10.1108/09604520610639955.

43. Kreziak, D., \& Frochot, I. (2011). Co-construction de l'expérience touristique Les stratégies des touristes en stations de sport d'hiver ( $\left.\mathrm{N}^{\circ} 64\right)$. $\mathrm{N}^{\circ} 64,23-33$.

44. Kurar, I. (2021). Research on the determination of recreational experience preferences, expectations, and satisfaction levels of local people: International Journal of Entrepreneurial Knowledge, 9(1), 41-66. https://doi.org/10.37335/ijek.v9i1.122

45. Ladhari, R. (2007). La satisfaction du consommateur, ses déterminants et ses conséquences. Revue de l’Université de Moncton, 36(2), 171-201. https://doi.org/10.7202/014503ar. 


\section{JOURNAL OF TOURISM AND SERVICES}

Issue 23, volume 12, ISSN 1804-5650 (Online)

www.jots.cz

46. Langlois.M. (2003). De la destination produit à la destination medium les cinq enjeux stratégiques de la gestion et du positionnement des destinations touristiques. Groupe de recherche sur le leadership stratégique et l'expérience client.

47. Laurette Dube-Rioux (1990). The Power of Affective Reports in Predicting Satisfaction Judgments. In NA - Advances in Consumer Research Volume 17, eds. Marvin E. Goldberg, Gerald Gorn, and Richard W. Pollay, Provo, UT : Association for Consumer Research, Pages: 571-576.

48. Lee, C.-K., Yoon, Y.-S., \& Lee, S.-K. (2007). Investigating the relationships among perceived value, satisfaction, and recommendations: The case of the Korean DMZ. Tourism Management, 28(1), 204-214. https://doi.org/10.1016/j.tourman.2005.12.017.

49. Lew, A. A., Cheer, J. M., Haywood, M., Brouder, P., \& Salazar, N. B. (2020). Visions of travel and tourism after the global COVID-19 transformation of 2020. Tourism Geographies, 22(3), 455-466. https://doi.org/10.1080/14616688.2020.1770326.

50. Loureiro, S. M. C., \& González, F. J. M. (2008). The Importance of Quality, Satisfaction, Trust, and Image in Relation to Rural Tourist Loyalty. Journal of Travel \& Tourism Marketing, 25(2), 117-136. https://doi.org/10.1080/10548400802402321.

51. Lyu, S. O., \& Hwang, J. (2015). Are the days of tourist information centers gone? Effects of the ubiquitous information environment. Tourism Management, 48, 54-63. https://doi.org/10.1016/j.tourman.2014.11.001.

52. Madani, A., Boutebal, S. E., \& Bryant, C. R. (2020). The Psychological Impact of Confinement Linked to the Coronavirus Epidemic COVID-19 in Algeria. International Journal of Environmental Research and Public Health, 17(10), 3604. https://doi.org/10.3390/ijerph17103604.

53. Marchat, Anne-Cecile. (2018). L'influence de la valeur perçue sur l'engagement client : vers une nouvelle approche de la relation "individu-destination" en tourisme. Université de la Réunion.

54. Michel, L. (n.d.). Rareté, utilité et valeur: L’approche économique. Hervé Dominique (Ed.). Pression Sur Les Ressources et Raretés. Montpellier : ORSTOM, 69-82.

55. Minvielle, J.-P., \& Minvielle, N. (2010). Le tourisme au Sahara: Pratiques et responsabilités des acteurs. Management \& Avenir, 33(3), 187. https://doi.org/10.3917/mav.033.0187.

56. Minvielle, J.-P., \& Minvielle, N. (2014). Le tourisme expérientiel au Sahara: Une construction hyperréelle de l'aventure. Mondes Du Tourisme, 10, 33-46. https://doi.org/10.4000/tourisme.375.

57. Molz, J. G. (2009). Representing pace in tourism mobilities: Staycations, Slow Travel and The Amazing Race. Journal of Tourism and Cultural Change, 7(4), 270-286. https://doi.org/10.1080/14766820903464242.

58. Mouhoud, E. M. (2020). L'économie politique du soulèvement algérien: Quelles perspectives $\begin{array}{llll}\text { pour la transition économique? } & 157 .\end{array}$ https://doi.org/10.3917/mouv.102.0157.

59. Naidoo, P., Ramseook-Munhurrun, P., \& Seegoolam, P. (2011). An assessment of visitor satisfaction with nature-based tourism attractions. International Journal of Management and Marketing Research, Vol. 4(No. 1), 87-98.

60. Neault, C. (2013). L'authenticité: Le point de vue du visiteur. Réseau de Veille En Tourisme.

61. Oliver, R. L. (1999). Whence Consumer Loyalty? Journal of Marketing, 63, 33. https://doi.org/10.2307/1252099.

62. Owusu-Frimpong, N., Nwankwo, S., Blankson, C., \& Tarnanidis, T. (2013). The effect of service quality and satisfaction on destination attractiveness of sub-Saharan African countries: The case of Ghana. Current Issues in Tourism, 16(7-8), 627-646. https://doi.org/10.1080/13683500.2013.785479. 


\section{JOURNAL OF TOURISM AND SERVICES}

Issue 23, volume 12, ISSN 1804-5650 (Online)

www.jots.cz

63. Parasuraman, A., Zeithaml, V. A., \& Berry, L. L. (1985). A Conceptual Model of Service Quality and Its Implications for Future Research. Journal of Marketing, 49(4), 41. https://doi.org/10.2307/1251430.

64. Pawitra, T. A., \& Tan, K. C. (2003). Tourist satisfaction in Singapore - a perspective from Indonesian tourists. Managing Service Quality: An International Journal, 13(5), 399-411. https://doi.org/10.1108/09604520310495868.

65. Perić, G., Dramićanin, S., \& Gašić, M. (2020). Impact of service quality on satisfaction and loyalty of tourists in rural tourism of Šumadija and Western Serbia. Ekonomika Poljoprivrede, 67(4), 1071-1086. https://doi.org/10.5937/ekoPolj2004071P .

66. Petit, S., \& Venayre, F. (2018). L’ouverture du marché polynésien du transport aérien international menacée par la communication de l'Autorité de la concurrence. Revue Juridique, Politique et Économique de Nouvelle-Calédonie.

67. Poulain, J.-P. (1998, July 26). Les patrimoines gastronomiques et leurs valorisations touristiques. Patrimoine Histoire et Mémoire. 14 Congrès Mondial de sociologie, Montréal, Canada.

68. Saayman, M., Li, G., Uysal, M., \& Song, H. (2018). Tourist satisfaction and subjective well-being: An index approach. International Journal of Tourism Research, 20(3), 388-399. https://doi.org/10.1002/jtr.2190

69. Salazar, N. B. (2006). Touristifying Tanzania. Annals of Tourism Research, 33(3), 833-852. https://doi.org/10.1016/i.annals.2006.03.017.

70. Salvador, M., \& El Euch Maalej, M. (2020). L'expérience touristique mémorable: Une approche par le produit alimentaire emblématique d'une région. Management \& Avenir, N¹16(2), 61. https://doi.org/10.3917/mav.116.0061.

71. Seetanah, B., Teeroovengadum, V., \& Nunkoo, R. (2020). Destination Satisfaction and Revisit Intention of Tourists: Does the Quality of Airport Services Matter? Journal of Hospitality \& Tourism Research, 44(1), 134-148. https://doi.org/10.1177/1096348018798446.

72. Simpson, D. (2016). The role of Visitor Information Centres: Information Centres still a leading information source during visits. Leisure Tourism Your Source for All Tourism, Leisure and Hospitality Information.

73. Spreng, R. A., MacKenzie, S. B., \& Olshavsky, R. W. (1996). A Reexamination of the Determinants of Consumer Satisfaction. Journal of Marketing, 60(3), 15. https://doi.org/10.2307/1251839 .

74. Willmott, L., \& R. Graci, S. (2012). Gestion des déchets solides dans les destinations insulaires de petite taille: Étude de cas sur Gili Trawangan, en Indonésie. Téoros, 31, 3.

75. Woyo, Erisher. (2021). The Sustainability of Using Domestic Tourism as a Post-COVID-19 Recovery Strategy in a Distressed Destination. Pp. 476-89 in Information and Communication Technologies in Tourism 2021, edited by W. Wörndl, C. Koo, and J. L. Stienmetz. Cham: Springer International Publishing.

76. Yüksel, A., \& Yüksel, F. (2001). Comparative performance analysis: Tourists' perceptions of Turkey relative to other tourist destinations. Journal of Vacation Marketing, 7(4), 333-355. https://doi.org/10.1177/135676670100700404 .

77. Zeithaml, V. A., Parasuraman, A., \& Berry, L. L. (1985). Problems and Strategies in Services Marketing. Journal of Marketing, 49(2), 33. https://doi.org/10.2307/1251563

\section{Brief description of Author/Authors:}

\section{Amina Chebli}

ORCID ID: https://orcid.org/0000-0003-0683-5482

Email address: $\underline{\text { a.chebli@,epau-alger.edu.dz }}$ 


\section{JOURNAL OF TOURISM AND SERVICES}

Issue 23, volume 12, ISSN 1804-5650 (Online)

www.jots.cz

Class B assistant professor on the École Polytechnique d'Architecture et Urbanisme d'Alger (EPAU). Algiers, Algeria. Affiliated to Ville, Urbanisme et development durable, laboratory (VUDD). Architect, a graduate of a master's degree in Urban Planning from Badji Mokhtar University. Department of Architecture, Annaba Algeria. Research Fields: urban tourism, tourism management, tourism attractiveness, and decision support tool.

\section{Boualem Kadri}

ORCID ID: ORCID : https://orcid.org/0000-0002-5416-6642

Email address: kadri.boualem@uqam.ca

Professor on Department of Urban and Tourism Studies of the School of Management, Universite du Québec à Montréal. He has a Master's degree in Tourism Management and Planning and a PhD in Urban Studies from the Université du Québec à Montréal. His research activities focus on the relationship between the city and tourism, including the process of tourism, metropolisation and governance issues in the cities of the Arab world, and the epistemology of tourism research.

\section{Foued Ben Said}

ORCID ID: https://orcid.org/0000-0001-6951-9490

E-mail: fdbs71@yahoo.fr; foued.bensaid@esct.uma.tn.

Associate- professor of statistics and Data analysis, department of Quantitative Methods, High School of Business, Manouba University, Tunisia. And member of the Research unity of Applied Econometrics in Finance; Tunis el Manar University.

Graduated in Applied statistics, Applied Econometrics and Quantitative and Qualitative Data Analysis. $\mathrm{He}$ has a PhD in Economic Sciences 2012. Research Fields: applied statistics, Applied Spatial Econometric, Quantitative and Qualitative data analysis; strategic analysis. 


\section{JOURNAL OF TOURISM AND SERVICES}

Issue 23, volume 12, ISSN 1804-5650 (Online)

www.jots.cz

Appendix 1. Measurement items of quality, satisfaction and loyalty

\begin{tabular}{|c|c|}
\hline PQ 01 & The Sahara is a vacation destination \\
\hline PQ 02 & The tourist reception in the region is reliable and constant \\
\hline PQ 03 & The Sahara represents no psychological risk (stress, anxiety, fear, etc.) \\
\hline PQ 04 & The Sahara is a safe destination \\
\hline PQ 05 & $\begin{array}{l}\text { In case of an accident, the Sahara is a destination where good medical care is offered } \\
\text { consistently and quickly }\end{array}$ \\
\hline PQ 06 & $\begin{array}{l}\text { The price of a trip to the Sahara is affordable (transportation, accommodation, food, and } \\
\text { activities) }\end{array}$ \\
\hline PQ 07 & $\begin{array}{l}\text { The Sahara is an easily accessible destination (well served by transportation: access by land, } \\
\text { regular flight schedule }\end{array}$ \\
\hline PQ 08 & $\begin{array}{l}\text { It is easy to get information about the destination (availability of tourist information offices, } \\
\text { service information relays, signage for entertainment and cultural information, etc.) }\end{array}$ \\
\hline PQ 09 & $\begin{array}{l}\text { In case of problems, you are well taken care of (in case of worries you are given help, very } \\
\text { professional, attentive and dedicated tourist guides) }\end{array}$ \\
\hline PQ 10 & The Saharan culture and atmosphere are very attractive \\
\hline PQ 11 & $\begin{array}{l}\text { The Sahara is a destination rich in entertainment (hiking, bivouac, } 4 \times 4 \text { safaris, camel rides, } \\
\text { musical evenings, cultural and historical discovery, etc.) }\end{array}$ \\
\hline PQ 12 & $\begin{array}{l}\text { In the Saharan hotels, the program of events is varied (if you have stayed in a hotel, give an } \\
\text { appreciation, otherwise choose indifferent) }\end{array}$ \\
\hline PQ 13 & In the South, the way people are dressed is attractive \\
\hline PQ 14 & The Sahara is a memorable destination rich in memories \\
\hline PQ 15 & Level of cleanliness is good \\
\hline PQ 16 & The Saharan cuisine is appetizing and very varied \\
\hline PQ 17 & The people of the Sahara are hospitable and welcoming \\
\hline PQ 18 & Saharan people are convincing and offer personalised service and care \\
\hline PQ 19 & $\begin{array}{l}\text { The local people have good communication skills to optimize the relationship with the } \\
\text { tourists }\end{array}$ \\
\hline PQ 20 & Saharan music is very captivating \\
\hline PQ 21 & The Sahara is endowed with enchanting landscapes \\
\hline PQ 22 & Service in the Sahara is prompt and fast \\
\hline PQ 23 & $\begin{array}{l}\text { Saharan hotels have very courteous and helpful staff (if you have stayed in a hotel, please rate } \\
\text { it, otherwise choose indifferent) }\end{array}$ \\
\hline S1 & You are satisfied with your experience in the Sahara \\
\hline S2 & Your trip to the Sahara provided you with the experience you were looking for \\
\hline S3 & You are satisfied with the services provided \\
\hline S4 & In general, your experience is very positive \\
\hline L1 & Visit this destination again \\
\hline $\mathrm{L} 2$ & Recommend this destination to my friends and relatives \\
\hline L3 & Visit this destination again in case of price increase of services \\
\hline
\end{tabular}

